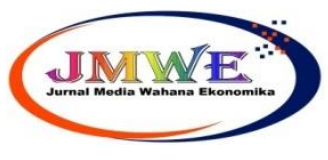

\title{
Hubungan Komunikasi Dan Budaya Organisasi Dengan Kinerja Pegawai DPPKA Kota Bengkulu
}

\author{
Ida Anggriani ${ }^{1}$, Marlina ${ }^{2}$ \\ ${ }^{1}$ Fakultas Ekonomi Universitas Dehasen Bengkulu, ida.anggriani26@gmail.com \\ ${ }^{2}$ Fakultas Ekonomi Universitas Dehasen Bengkulu
}

\begin{abstract}
ABSTRAK
Komunikasi yang dilakukan oleh pegawai merupakan hal yang kompleks, tanpa adanya komunikasi maka pegawai tidak dapat saling memahami satu sama lain, dan akhirnya tidak dapat mencapai tujuannya dengan optimal. Dalam suatu organisasi juga memiliki latar belakang budaya yang berbeda, maka kesalahan penerapan budaya yang tidak tepat dalam sebuah organisasi akan menjadikan organisasi mengalami permasalahan yang dapat menurunkan kinerja pegawai dan berdampak buruk akan keberlangsungan hidup organisasi. Metode pengumpulan data penelitian ini adalah dengan cara kuesioner yang disebarkan kepada 50 orang responden. Penelitian ini menggunakan analisis korelasi rank spearman dan pengujian hipotesis $t$ untuk menganalisis data yang diperoleh mengenai hubungan komunikasi dan budaya organisasi dengan kinerja pegawai DPPKA Kota Bengkulu. Dari hasil penelitian berdasarkan perhitungan koefisien korelasi rank spearman, diketahui nilai korelasi antara komunikasi dengan kinerja sebesar 0,81 artinya terdapat hubungan yang sangat kuat antara komunikasi dengan kinerja pegawai pada dinas pendapatan, pengelolaan keuangan dan aset kota bengkulu sedangkan nilai korelasi antara budaya organisasi dengan kinerja sebesar 0,77 artinya terdapat hubungan yang kuat antara budaya organisasi dengan kinerja pegawai pada dinas pendapatan, pengelolaan keuangan dan aset kota bengkulu. Hasil uji hipotesis diketahui bahwa nilai $t$ hitung antara komunikasi dengan kinerja pegawai sebesar 9,622 sedangkan nilai t hitung antara budaya organisasi dengan kinerja pegawai sebesar 8,331 , dari nilai tersebut menunjukkan nilai $t$ hitung lebih besar dari t tabel $(1,677)$, sehingga ho ditolak dan ha diterima, artinya terdapat hubungan yang signifikan terhadap variabel $\mathrm{x}_{1}$ dan $\mathrm{x}_{2}$ (komunikasi dan budaya organisasi) dengan variabel $\mathrm{y}$ (kinerja) para pegawai yang bekerja pada dinas pendapatan, pengelolaan keuangan dan aset (DPPKA) Kota Bengkulu.
\end{abstract}

Kata Kunci : Komunikasi, Budaya Organisasi, Kinerja

\begin{abstract}
Communication carried out by employees is complex, without communication, employees cannot understand each other, and ultimately cannot achieve their goals optimally. In an organization that also has a different cultural background, the incorrect application of an inappropriate culture in an organization will cause the organization to experience problems that can reduce employee performance and have a negative impact on the survival of the organization. Method data collecting of this research is by propagated kuesioner to 50 responder people. Analysis method the used is correlation of rank hypothesis test and spearman with test of $t$. Pursuant to calculation of correlation coefficient of rank spearman, known by correlation value between communications with performance equal to its 0,81 meaning there are very strong relation between communications with performance employee at Duty Earnings, Management of Finance and Asset Town of Bengkulu while correlation value between organizational culture with performance equal to its 0,77 meaning there are strong relation between organizational culture and communications with officer performance at Duty Earnings, Management of Finance and Asset Town of Bengkulu. Result of hypothesis test known that value of $t$ count between communications with performance equal to 9,622 while value of $t$ count between organizational culture with performance equal to 8,331 bigger than 1,677, so that Ho refused and $\mathrm{Ha}$ accepted by its meaning there is relation which is significant between organizational culture and communications with officer performance at On Duty Earnings, Management of Finance and Asset Town of Bengkulu.
\end{abstract}

Keywords : Communications, Organization Cultural, performance 


\section{A. PENDAHULUAN}

Berbagai aktifitas yang dilakukan oleh manusia dalam menjalankan kehidupan membawa manusia menjadi mahluk yang memiliki peradaban paling tinggi jika dibandingkan dengan mahluk lain di bumi, akal dan fikiran manusia yang lebih unggul dari mahluk lainnya membuat manusia menciptakan komunikasi yang baik dan budaya dalam kehidupan sosialnya dan hal inilah yang membedakan status manusia dengan mahluk lainnya.

Komunikasi dan budaya ini sangat dibutuhkan di berbagai aspek kehidupan manusia baik dalam dalam keluarga ataupun dalam cakupan yang lebih luas yaitu bermasyarakat. Fungsi komunikasi dan budaya juga terdapat pada kehidupan berorganisasi dalam dunia kerja. Sumber daya manusia selaku pelaksana roda organisasi haruslah memiliki kemampuan komunikasi yang dianggap baik dan dapat mewujudkan eksistensi budaya organisasi yang dianggap sesuai dan diterima secara universal oleh seluruh pegawai yang ada.

Komunikasi yang dilakukan oleh manusia merupakan hal yang kompleks, karena manusia menggunakan bahasa dan isyarat dalam menyampaikan maksud dan tujuan yang dimilikinya kepada manusia lain. Tanpa adanya komunikasi yang dilakukan maka manusia tidak dapat saling memahami satu sama lain, dan akhirnya manusia tidak dapat mencapai tujuannya dengan optimal. Maka dari itu organisasi memerlukan komunikasi dan organisasi harus senantiasa memperhatikan bagaimana komunikasi yang dilakukan oleh pegawai yang bekerja didalamnya berjalan dengan efektif dan membantu pegawai dalam menyelesaikan tugasnya dengan baik.

Selanjutnya mengenai budaya, dalam sebuah organisasi budaya yang dapat diterima dengan baik oleh pegawai adalah hal yang penting, karena pegawai memiliki latar belakang budaya yang berbeda, maka kesalahan penerapan budaya yang tidak tepat dalam sebuah organisasi akan menjadikan organisasi mengalami permasalahan yang dapat menurunkan kinerja pegawai dan berdampak buruk akan keberlangsungan hidup organisasi.

Pada dasarnya organisasi juga memiliki kepribadian seperti individu manusia, dimana keperibadian pada sebuah organisasi biasa dikenal dengan nama budaya organisasi. Pada organisasi yang dijalankan maka budaya organisasi akan membentuk sebuah identitas dari organisasi itu sendiri sebagai jati diri yang melekat pada organisasi, dengan demikian maka dapat dikatakan bahwa identitas dalam sebuah organisasi sangat diperlukan oleh organisasi itu sendiri untuk memupuk rasa bangga ketika pegawai yang bekerja dalam organisasi dapat mengembangkan budaya kerja nya ke arah yang lebih baik.

Citra baik organisai akan terbentuk apabila seluruh karyawan atau pegawai yang ada dalam organisasi menjalankan budaya organisasi sesuai dengan tujuan dalam organisasi, sehingga organisasi dapat berjalan sesuai dengan apa yang ditujukan untuk organisasi tersebut. Pada dasarnya budaya organisasi yang baik dapat terlihat dari apa saja yang menjadi nilai yang disepakati dalam organisasi secara luas, dan dijalankan sesuai dengan kesepakatan yang telah dilaksanakan.

Kita dapat memanfaatkan budaya kerja dalam sebuah organisasi, apabila budaya kerja yang dibentuk mengkuti kebutuhan organisasi, hal ini baik untuk organisasi menghadapi persaingan dimana organisasi dapat mengandalkan budaya organisasi sebagai pembanding dengan organisasi lain serta dapat memberikan jawaban terhadap tantangan dan perubahan yang kian cepat pada era ini. 
Pada akhirnya budaya organisasi yang kuat dan disepakati bersama tersebut dapat memberikan fungsi sebagai rantai pengikat dalam proses menyamakan persepsi atau arah pandang anggota organisasi atau pegawai terhadap sebuah analisis masalah yang terjadi, sehingga hal ini dapat dijadikan satu kekuatan bagi organisasi untuk mencapai tujuan organisasi itu sendiri.

Semakin banyak anggota organisasi yang merupakan pegawai yang bekerja menerima nilai-nilai inti maka semakin besar komitmen mereka terhadap nilai-nilai tersebut dan semakin kuat pula suatu budaya yang tertanam. Diketahui bahwa budaya yang kuat dalam sebuah organisasi dapat memberikan pengaruh yang cukup besar pada sikap yang ditunjukkan oleh anggota organisasi pada umumnya, sehingga baik buruknya sikap dari anggota organisasi yang bekerja dapat ditinjau dari seberapa kuat adaptasi yang dilakukan oleh anggota organisasi dalam menjalankan budaya kerja yang sudah disepakati tersebut.

Spesifik atau tidak hasil dari budaya yang dibentuk dalam sebuah organisasi merupakan gambaran dari rendahnya jumlah pegawai yang bertahan atau pergi dari organisasi pada periode waktu tertentu, dengan demikian dapat dikatakan bahwa budaya yang dianggap kuat dalam sebuah organisasi akan dapat menunjukkan bagaimana kesepakatan dapat dijunjung tinggi, dan isi dari kesepakatan tersebut adalah tujuan-tujuan organisasi yang dibentuk secara koheren oleh anggotanya, dengan demikian tujuan dapat dicapai dengan semaksimal mungkin oleh organisasi.

Dinas Pendapatan Pengelolaan Keuangan dan Aset (DPPKA) Kota Bengkulu merupakan organisasi Pemerintah Daerah yang mengurus permasalahan pendapatan pengelolaan keuangan dan aset Kota Bengkulu, dan dalam pelaksanaan pekerjaannya maka sumber daya manusia yang bekerja tersebut haruslah mempunyai kemampuan komunikasi yang baik dan menciptakan budaya yang mampu mendorong pegawai agar dapat melaksanakan pekerjaan dengan maksimal. Kebutuhan akan efektifitas komunikasi dengan standar dan kualitas yang baik oleh pegawai Pendapatan Pengelolaan Keuangan dan Aset (DPPKA) Kota Bengkulu akan membuat pegawai mampu memahami dengan jelas berbagai pekerjaan yang harus dilakukakannya dan pegawai akan mampu menyelesaikan pekerjaan tersebut dengan maksimal. Pada kenyataannya pada Dinas Pendapatan Pengelolaan Keuangan dan Aset (DPPKA) Kota Bengkulu dalam hal komunikasi masih terdapat kendala seperti pesan/informasi/instruksi yang diterima oleh masing-masing pegawai belum dapat dipahami dengan baik oleh pegawai sedangkan dalam hal budaya kerja masih terlihat pegawai kurang mampu dalam berkoordinasi dan mengendalikan diri yang lebih baik dalam pelaksanaan pekerjaannya masing-masing serta masih dirasakan oleh pegawai kurangnya dukungan dari atasan.

Berdasarkan kendala tersebut di atas dan mengingat komunikasi dan budaya organisasi dalam organisasi harus dijalankan dengan baik pada akhirnya dapat mendorong pegawai bekerja dengan maksimal dan mampu meningkatkan kinerja pegawai yang bekerja pada Dinas Pendapatan Pengelolaan Keuangan dan Aset (DPPKA) Kota Bengkulu sehingga peneliti memiliki ketertarikan untuk melakukan pengamatan yang mendalam mengenai "Hubungan Komunikasi dan Budaya OrganisasiDengan Kinerja Pegawai pada Dinas Pendapatan Pengelolaan Keuangan dan Aset (DPPKA) Kota Bengkulu".

Untuk melakukan penelitian yang berbasis pada fakta dan data yang valid serta tidak keluar dari konteks pembahasan yang jelas maka penulis memutuskan untuk memberikan batasan masalah yang jelas dalam melakukan penelitian, dimana batasan masalah yang penulis sepakati adalah permasalahan "Hubungan 
komunikasi dan budaya organisasi dengan kinerja pegawai pada Dinas Pendapatan Pengelolaan Keuangan dan Aset (DPPKA) Kota Bengkulu" Pegawai yang dimaksud dalam penelitian ini adalah khusus pegawai yang berstatus PNS. Adapun variabel dan indikator penelitian ini adalah: Variabel komunikasi dengan indikator menurut Mas'ud (2012:74) yaitu: Bijaksana dan kesopanan, peneriaan umpan balik, berbagi informasi, memberikan informasi tugas, mengurangi ketidak pastian tugas. Variabel budaya organisasi dengan indikatornya menurut Umar (2013:208) yaitu: Inisiatif individu, toleransi terhadap tindakan berisiko, arah, integrasi, dukungan manajemen, kontrol, identitas. Variabel kinerja dengan indikatornya menurut Mathis dan Jackson (2014:115) yaitu: kemampuan individual, usaha yang dicurahkan, dukungan organisasional.

Tujuan penelitian ini adalah untuk mengetahui hubungan komunikasi dan budaya organisasi dengan kinerja pegawai pada Dinas Pendapatan Pengelolaan Keuangan dan Aset (DPPKA) Kota Bengkulu. Dari penelitian ini diharapkan akan dapat membantu Dinas Pendapatan Pengelolaan Keuangan dan Aset (DPPKA) Kota Bengkulu dalam meningkatkan kinerja pegawai melalui peningkatan kemampuan komunikasi pegawai dan menetapkan budaya organisasi yang mampu membuat pegawai menjadi terdorong untuk bekerja lebih optimal.

\section{B. KAJIAN TEORI}

\section{Komunikasi}

Dalam kehidupan sehari hari, di masyarakat, dalam dunia bisnis, dalam organisai manusia saling berkomunikasi. Komunikasi diartikan sebagai suatu kegatan manusia yang satu dengan lainnya untuk pertukaran informasi. Komunikasi merupakan faktor dalam pencapaian tujuan organisasi dimana dalam berkomunikasi dapat dilakukan dengan berbagai media baik elektronik maupun non elektronik. Sebagaimana dikatakan oleh Himstreet dan Wayne dalam Purwanto (2011:3) bahwa komunikasi adalah proses pertukaran informasi melalui suatu sistem yang biasa terjadi melalui simbol-simbol, sinyal, tindakan maupun perilaku antar individu.

Muhammaad Jabin dalam Mas'ud (2012:74), berpendapat bahwa ada beberapa indikator yang digunakan untuk mengukur komunikasi dalam organisasi yaitu :

1. Bijaksana dan sopan, maksudnya adalah dalam berkomunikasi menggunakan kata dan kalimat yang efektif dengan bahasa yang sopan.

2. Penerimaan Umpan Balik maksudnya ada tanggapan terhadap isi pesan yang disampaikan

3. Berbagi Informasi, maksudnya adanya informasi tentang kemajuan dan permasalahan yang ada terhadap rekan sejawat maupun pimpinan

4. Informasi tugas, maksudnya adanya informasi tentang sesuatu yang berkaitan dengan tugas

5. Mengurangi ketidakpastian tugas, maksudnya ada informasi lengkap dan jelas tentang tugas agar dapat diselesaikan sesuai harapan.

\section{Budaya Organisasi}

Robbins dalam Sopiah (2008:128) mengatakan bahwa budaya organisasi mengacu pada suatu sistem bersama yang dianut para anggotanya yang mempunyai ciri khas yang berbeda dengan organisasi lainnya. Umar (2013:208) berpendapat bahwa faktor utama dalam penilaian kualitas budaya organisasi yaitu :

a. Inisiatif individu artinya individu mempunyai tingkat tanggung jawab, kebebasan dan independensi. 
b. Toleransi terhadap tindakan beresiko artinya yaitu sejauhmana pegawai bertindak agresif, inovatif dan berani mengambil resiko.

c. Arah, artinya sejauh mana organisasi dapat menciptakan sasaran dan harapan mengenai prestasi secara jelas

d. Integrasi, artinya sejauhmana unit-unit dalam organisasi didorong bekerja secara terkoordinasi.

e. Dukungan manajemen artinya sejauhmana manajer dapat berkomunikasi dengan jelas, memberikan bantuan dan dukungan kepada bawahannya.

f. Kontrol, yaitu berupa peraturan dan pengawasan langsung yang terapkan dalam mengawasi dan mengendalikan perilaku pegawai.

g. Identitas, yaitu sejauhmana pegawai mengidentifikasi dirinya secara keseluruhan dengan organisasinya daripada dengan kelompok.

\section{Kinerja}

Bangun (2012:231) mengemukakan kinerja merupakan hasil pekerjaan yang dicapai pegawai berdasarkan persyaratan pekerjan.

Faktor utama yang mempengaruhi bagaimana kinerja seorang pegawai antara lain (Mathis \& Jackson, 2014:115):

a. Kemampuan individual yaitu komponen kemampuan individ yang terdiri dari bakat, minat, dan faktor kepribadian individu.

b. Usaha yang dicurahkan yaitu komponen dari usaha yang dicurahkan berupa motivasi, rancangan tugas, etika kerja, dan kehadiran

c. Dukungan organisasional yaitu komponen dukungan organisasional berupa pelatihan dan pengembangan, peralatan/teknologi, standar kinerja, dan manajemen dan rekan sejawat

\section{Hipotesis}

Hipotesis penelitian ini adalah :

1. Diduga komunikasi mempunyai hubungan signifikan dengan kinerja pegawai DPPKA Kota Bengkulu.

2. Diduga budaya organisasi mempunyai hubungan signifikan dengan kinerja pegawai pegawai DPPKA Kota Bengkulu.

\section{METODE PENELITIAN}

Penulis memilih jenis penelitian survey untuk menggali masalah dalam penelitian ini, adapun yang dimaksud dengan penelitian survey adalah penelitian yang dilakukan dengan menentukan sampel penelitian dalam sebuah populasi yang berkaitan dengan kajian masalah penelitian sehingga penulis pada akhirnya mampu untuk menjelaskan kesenjangan masalah agar dapat terlihat jelas. Penelitian survey ini menggunakan kuesioner untuk disebarkan kepada responden dan juga sebagai alat ukur yang digunakan untuk analisis data sesuai dengan fakta dilapangan. Penelitian survey adalah suatu metode penelitian yang mengambil sampel dari satu populasi dengan menggunakan kuesioner sebagai alat pengambilan data yang pokok (Singarimbun dan Effendy (2009:3). Melalui penelitian ini diharapkan dapat memberikan gambaran yang jelas mengenai hubungan komunikasi dan budaya organisasi dengan kinerja pegawai pada Dinas Pendapatan Pengelolaan Keuangan dan Aset (DPPKA) Kota Bengkulu.

Penelitian ini dilakukan pada lokasi kantor DPPKA Kota Bengkulu. Populasi dalam penelitian ini berjumlah 99 orang pegawai yang berstatus pegawai negeri sipil pada Dinas Pendapatan Pengelolaan Keuangan dan Aset (DPPKA) Kota 
Bengkulu. Menurut Arikunto (2014:116) bahwa jika subyek penelitian besar maka dapat diambil sampelnya antara 10 - $15 \%$ atau 20 - $55 \%$. Berdasarkan pendapat tersebut maka jumlah sampel yang diambil pada penelitian ini adalah sebanyak $50 \%$ dari populasi yaitu $99: 2=49,5$ orang dibulatkan menjadi 50 orang. Artinya sampel yang diambil berjumlah 50 orang pegawai negeri sipil pada Dinas Pendapatan Pengelolaan Keuangan dan Aset (DPPKA) Kota Bengkulu, sedangkan metode pengambilan sampel penelitian dengan cara acak, artinya siapapun mempunyai peluang yang sama untuk dijadikan sampel penelitian.

Tehnik pengumpulan data yang digunakan dalam penelitian adalah dengan menggunakan kuesioner/daftar pertanyaan dalam rangka untuk memperoleh data dan informasi dari pegawai pada Dinas Pendapatan Pengelolaan Keuangan dan Aset (DPPKA) Kota Bengkulu. Adapun alternatif jawaban dalam kuesioner penelitian ini menggunakan skala likert (Sugiyono, 2014:133) dengan alternatif jawaban sebagai berikut :

\begin{tabular}{|} 
TABEL SKALA LIKERT \\
\begin{tabular}{|c|c|}
\hline ALTERNATIF JAWABAN & SKOR \\
\hline Sangat Setuju (SS) & 5 \\
Setuju (S) & 4 \\
Cukup Setuju (CS) & 3 \\
Tidak Setuju (TS) & 2 \\
Sangat Tidak Setuju (STS) & 1 \\
\hline Sumber : Sugiyono, 2014:133
\end{tabular}
\end{tabular}

Metode analisis yang digunakan dalam penelitian ini adalah:

1. Korelasi Rank Spearman

Menurut Sugiyono (2014:357), Korelasi Rank Spearman adalah korelasi yang digunakan untuk mencari hubungan atau pengujian signifikansi hipotesis asosiatif, jika variable memiliki data dalam bentuk ordinal, dan sumber data belum tentu sama. Rumus korelasi Spearman Rank adalah :

$$
\begin{aligned}
\rho & =1-\frac{6 \sum b_{i}{ }^{2}}{n\left(n^{2}-1\right)} \\
\rho & =\text { Koefisien Korelasi Spearman Rank } \\
b_{i}^{2} & =\text { Kuadrat perbedaan setiap pasang rank } \\
\mathrm{n} & =\text { Jumlah data }
\end{aligned}
$$

Adapun cara agar dapat mengetahui hubungan/korelasi antara variabel komunikasi dan budaya organisasi dengan kinerja pegawai pada Dinas Pendapatan Pengelolaan Keuangan dan Aset (DPPKA) Kota Bengkulu digunakan interpretasi korelasi sebagai berikut :

TABEL INTERPRETASI KOEFISIEN KORELASI

\begin{tabular}{|c|c|}
\hline INTERVAL KOEFISIEN & TINGKAT HUBUNGAN \\
\hline $0,000-0,199$ & Sangat Rendah \\
\hline $0,200-0,399$ & Rendah \\
\hline $0,400-0,599$ & Sedang \\
\hline $0,600-0.799$ & Kuat \\
\hline $0,800-1,000$ & Sangat Kuat \\
\hline
\end{tabular}

Sumber : Sugiyono (2014:250) 


\section{Uji hipotesis}

Hubungan yang signifikan atau tidak dalam penelitian ini dapat dilihat dari data yang sudah dianalisis dengan uji hipotesis t. Adapun rumus yang digunakan dalam mengamati signifikasi hubungan variabel $X_{1}$ dan $X_{2}$ terhadap $Y$ adalah sebagai berikut:

$$
\begin{aligned}
& \mathrm{t} \text { hitung }=r \sqrt{\frac{n-2}{1-r^{2}}} \\
& \mathrm{r}=\text { nilai korelasi yang diperoleh } \\
& \mathrm{n}=\text { Jumlah banyaknya sampel/data }
\end{aligned}
$$

Pengujian hipotesis sebagai berikut: Penentuan tingkat keyakinan/level of significant adalah $95 \%$ dengan tingkat penyimpangan atau $\alpha=0,05$. Dengan kriteria pengujian hipotesis sebagai berikut :

a. Ho ditolak dan Ha diterima jika $t$ hitung $>t$ tabel, berarti terdapat hubungan yang signifikan antara komunikasi dan budaya organisasi dengan kinerja pegawai pada Dinas Pendapatan Pengelolaan Keuangan dan Aset (DPPKA) Kota Bengkulu.

b. Ho diterima dan $\mathrm{Ha}$ ditolak jika $\mathrm{t}$ hitung $<\mathrm{t}$ tabel, berarti tidak terdapat hubungan yang signifikan antara komunikasi dan budaya organisasi dengan kinerja pegawai pada Dinas Pendapatan Pengelolaan Keuangan dan Aset (DPPKA) Kota Bengkulu.

\section{HASIL DAN PEMBAHASAN}

Berdasarkan hasil analisis data yang dilakukan dengan menggunakan metode survey dang menggunakan rumus spearman rank serta di uji hipotesis nya dengan uji t maka dapat melihat hasil nya pada tabel berikut:

TABEL HASIL KORELASI RANK SPEARMAN

\begin{tabular}{|c|c|c|}
\hline \multirow{2}{*}{ Variabel } & \multicolumn{2}{|c|}{ Korelasi Rank Spearman } \\
\cline { 2 - 3 } & $\boldsymbol{\rho}$ hitung & Kriteria \\
\hline $\mathrm{X} 1-\mathrm{Y}$ & 0,81 & Sangat Kuat \\
\hline $\mathrm{X} 2-\mathrm{Y}$ & 0,77 & Kuat \\
\hline
\end{tabular}

Sumber : Hasil Penelitian, Diolah

TABEL HASIL UJI HIPOTESIS

\begin{tabular}{|c|c|c|c|}
\hline \multirow{2}{*}{ Variabel } & \multicolumn{3}{|c|}{ Uji Hipotesis } \\
\cline { 2 - 4 } & t hitung & t tabel & Kriteria \\
\hline $\mathrm{X} 1-\mathrm{Y}$ & 9,622 & 1,677 & Signifikan \\
\hline $\mathrm{X} 2-\mathrm{Y}$ & 8,331 & 1,677 & Signifikan \\
\hline
\end{tabular}

Sumber : Hasil Penelitian, Diolah

Berdasarkan hasil analisis yang dilakukan oleh peneliti diketahui bahwa nilai korelasi antara komunikasi dengan kinerja sebesar 0,81, artinya terdapat hubungan yang sangat kuat antara komunikasi dengan kinerja pegawai pada Dinas Pendapatan, Pengelolaan Keuangan dan Aset Kota Bengkulu. Sedangkan nilai korelasi antara budaya organisasi dengan kinerja sebesar 0,77 artinya terdapat hubungan yang kuat antara budaya organisasi dengan kinerja pegawai pada Dinas Pendapatan, Pengelolaan Keuangan dan Aset Kota Bengkulu. 
Dari hasil uji hipotesis diketahui bahwa nilai t hitung antara komunikasi dengan kinerja pegawai pada Dinas Pendapatan, Pengelolaan Keuangan dan Aset Kota Bengkulu adalah sebesar 9,622, lebih besar daripada t tabel 1,677. Sedangkan nilai hitung antara komunikasi dan budaya organisasi dengan kinerja pegawai pada Dinas Pendapatan, Pengelolaan Keuangan dan Aset Kota Bengkulu adalah sebesar 8,331, lebih besar daripada t tabel 1,677, sehingga Ho ditolak dan Ha diterima artinya ada hubungan signifikan antara komunikasi dan budaya organisasi dengan kinerja pegawai pada Dinas Pendapatan, Pengelolaan Keuangan dan Aset Kota Bengkulu.

Hasil analisis yang telah dilakukan membuktikan bahwa pentingnya komunikasi dan budaya organisasi yang baik dalam peningkatan kinerja pegawai yang bekerja pada Dinas Pendapatan, Pengelolaan Keuangan dan Aset Kota Bengkulu, diketahui bahwa unsur dalam komunikasi merupakan hal pokok yang harus dilakukan dalam seluruh aspek kegiatan maka dari itu dengan mempertahankan komunikasi agar tetap berjalan dengan kondusif dan fungsi komunikasi tersebut berjalan dengan efektif merupakan hal yang harus dilakukan oleh Dinas Pendapatan, Pengelolaan Keuangan dan Aset Kota Bengkulu.

Komunikasi akan memberikan dampak yang besar bagi kemajuan sebuah organisasi begitupula dengan Dinas Pendapatan, Pengelolaan Keuangan dan Aset Kota Bengkulu, dimana semua kegiatan menggunakan komunikasi dalam penyampaiannnya, sehingga setiap poin yang disepakati bersama dapat saling dipahami dan ditindaklanjuti agar tujuan dari Dinas Pendapatan, Pengelolaan Keuangan dan Aset Kota Bengkulu dapat tercapai dengan maksimal.

Komunikasi merujuk pada kegiatan yang sangat penting, sehingga dengan memastikan bahwa komunikasi yang akan disampaikan mampu menjadi efektif maka kegiatan dalam pelaksanaan pekerjaan pada Dinas Pendapatan, Pengelolaan Keuangan dan Aset Kota Bengkulu akan berjalan dengan baik, dan apabila kegiatan komunikasi tidak efektif, dan banyak pegawai yang tidak memahami informasi yang disampaikan satu dengan yang lainnya maka hal yang tidak diinginkan pun bisa jadi akan terjadi, misalnya ketidaksesuaian tindakan kerja pegawai Dinas Pendapatan, Pengelolaan Keuangan dan Aset Kota Bengkulu dengan apa yang telah diperintahkan kepadanya.

Pada dasarnya kegiatan komunikasi yang dilakukan oleh seluruh pegawai pada Dinas Pendapatan, Pengelolaan Keuangan dan Aset Kota Bengkulu telah dijalankan dengan baik dan sesuai dengan standar komunikasi yang sudah ada, ini terlihat dari jawaban responden yang menyatakan bahwa kegiatan komunikasi yang dijalankan oleh pegawai Dinas Pendapatan, Pengelolaan Keuangan dan Aset Kota Bengkulu, menerapkan kebijaksanaan dan kesopanan, sehingga pegawai merasa senang dengan komunikasi yang dilakukan.

Penerimaan umpan balik yang dilakukan atas hasil komunikasi yang dijalankan oleh Dinas Pendapatan, Pengelolaan Keuangan dan Aset Kota Bengkulu pesan yang disampaikan diterima dan dapat dipahami dengan baik sehingga pegawai Dinas Pendapatan, Pengelolaan Keuangan dan Aset Kota Bengkulu mampu memberikan umpan balik/tanggapan atas pesan yang disampaikan.

Dalam menjalankan komunikasi, pegawai Dinas Pendapatan, Pengelolaan Keuangan dan Aset Kota Bengkulu membagikan informasi dengan tingkat transparansi yang cukup optimal, salah satu kegiatan pembagian informasi tersebut adalah dengan selalu memberikan informasi kemajuan pekerjaan, permasalahan pekerjaan dan informasi tugas kepada rekan kerja maupun pimpinan sehingga semua kendala dapat ditindaklanjuti dengan cepat dan tepat. 
Dalam melaksanakan pekerjaannya pegawai Dinas Pendapatan, Pengelolaan Keuangan dan Aset Kota Bengkulu menggunakan kegiatan komunikasi dengan baik, dan memanfaatkan kegiatan komunikasi tersebut sehingga ketidakpastian dalam pelaksanaan tugas dapat diminimalisir, dan pegawai tidak akan melaksanakan pekerjaan yang dianggap sia-sia dalam mencapai tujuan Dinas Pendapatan, Pengelolaan Keuangan dan Aset Kota Bengkulu.

Hal ini sesuai dengan yang dikemukakan William I. Gorden dalam Mulyana (2014:5) bahwa komunikasi sangat penting dan berfungsi untuk membangun konsep dan aktualisasi diri, kelangsungan hidup, kebahagiaan, terhindar dari tekanan dan ketegangan melalui komunikasi yang bersifat menghibur, dan memupuk hubungan dengan orang lain. Komunikasi juga berfungsi untuk menyampaikan perasaanperasaan (emosi) terutama dikomunikasikan melalui perasaan-perasaan non verbal. Komunikasi juga bertujuan menginformasikan, mengajar, mendorong, mengubah sikap, menggerakkan tindakan, dan juga menghibur.

Komunikasi dan kinerja pegawai saling berhubungan erat dan mempengaruhi. Ketika komunikasi ditempat kerja tersampaikan dengan jelas dan dapat meminimalisir tingkat stres pegawai, maka kinerja pegawai juga akan berkorelasi positif.

Selanjutnya adalah bagaimana budaya organisasi yang dijalankan dan di terapkan pada Dinas Pendapatan, Pengelolaan Keuangan dan Aset Kota Bengkulu mampu membentuk pegawai dengan tingkat kinerja yang tinggi. Budaya organisasi merupakan kebiasaan-kebiasaan yang dilakukan diorganisasi dan sudah ada sejak lama dalam organisasi tersebut.

Hal tersebut sejalan dengan pendapat sebagaimana dikemukakan oleh Robbins (2009:311) terdapat fungsi yang dijalankan ketika organisasi sedang dijalankan, dimana diantara fungsi tersebut adalahmenciptakan menciptakan pembedaan yang jelas antara satu organisasi dengan organisasi yang lain, identitas bagi anggota-anggota organisasi, mempermudah timbulnya komitmen yang luas daripada kepentingan pribadinya, perekat sosial dalam organisasi. Dari pendapat menunjukkan bahwa betapa penting budaya organisasi dalam suatu organisasi.

Keadaan budaya organisasi yang baik ataupun tidak baik akan memberikan dampak bagi kemajuan organisasi begitupula dengan Dinas Pendapatan, Pengelolaan Keuangan dan Aset Kota Bengkulu. Dengan adanya budaya organisasi yang baik yang diterapkan oleh Dinas Pendapatan, Pengelolaan Keuangan dan Aset Kota Bengkulu dan mampu membentuk pegawai yang memiliki tingkat kerja yang baik maka budaya organisasi juga akan mampu mencapai tujuan dan harapan Dinas Pendapatan, Pengelolaan Keuangan dan Aset Kota Bengkulu secara keseluruhan.

Budaya organisasi pada Dinas Pendapatan, Pengelolaan Keuangan dan Aset Kota Bengkulu mampu membentuk pegawai yang bekerja didalamnya memiliki insiatif yang tinggi ketika menghadapi permasalahan dalam pekerjaannya, serta memiliki toleransi terhadap tindakan berisiko sehingga pegawai Dinas Pendapatan, Pengelolaan Keuangan dan Aset Kota Bengkulu mampu untuk meminimalisir risiko kerja yang mungkin saja akan terjadi.

Dinas Pendapatan, Pengelolaan Keuangan dan Aset Kota Bengkulu mampu menciptakan dengan jelas sasaran dan harapan mengenai prestasi yang harus diperoleh oleh setiap pegawai yang bekerja didalamnya, serta mampu mendorong unit-unit pada Dinas Pendapatan, Pengelolaan Keuangan dan Aset Kota Bengkulu untuk bekerja dengan cara terkoordinasi karena sudah adanya budaya yang jelas dan baik. 
Budaya organisasi pada Dinas Pendapatan, Pengelolaan Keuangan dan Aset Kota Bengkulu juga membudayakan mengenai dukungan manajemen terhadap pegawai, dimana pimpinan pada Dinas Pendapatan, Pengelolaan Keuangan dan Aset Kota Bengkulu mampu memberikan komunikasi yang jelas kepada para pegawai, dan selalu memberikan bantuan serta dukungan terhadap bawahan pada Dinas Pendapatan, Pengelolaan Keuangan dan Aset Kota Bengkulu.

Pegawai Dinas Pendapatan, Pengelolaan Keuangan dan Aset Kota Bengkulu merasa bahwa kontrol yang dilakukan pada Dinas Pendapatan, Pengelolaan Keuangan dan Aset Kota Bengkulu sudah dijalankan dengan baik dengan adanya kesesuaian antara tugas yang diberikan pimpinan terhadap kemampuan pegawai, serta kesesuaian jumlah peraturan dan pengawasan langsung yang digunakan untuk mengawasi dan mengendalikan perilaku pegawai.

Budaya organisasi pada Dinas Pendapatan, Pengelolaan Keuangan dan Aset Kota Bengkulu juga menciptakan identitas yang baik dalam pelaksanaan pekerjaannya, ini terlihat dari adanya pengetahuan pegawai mengenai tugas masingmasing dan mempu mengidentifikasi diri dalam pelaksanaan pekerjaan masingmasing.

Dengan komunikasi dan budaya organisasi yang dijalankan dengan baik dan positif pada Dinas Pendapatan, Pengelolaan Keuangan dan Aset Kota Bengkulu maka sudah dapat dikatakan bahwa kinerja pegawai pada Dinas Pendapatan, Pengelolaan Keuangan dan Aset Kota Bengkulu juga dalam keadaan yang baik, pegawai diketahui memiliki kemampuan individual yang baik dengan memiliki bakat, minat, dan kepribadian yang baik dalam bekerja.

Pegawai pada Dinas Pendapatan, Pengelolaan Keuangan dan Aset Kota Bengkulu mencurahkan seluruh usahanya dalam menyelesaikan pekerjaan, dilihat dari adanya motivasi dalam diri pegawai, penerapan etika, dan pengupayaan tingkat hadir yang tinggi pada saat pelaksanaan pekerjaan. Dengan memiliki ketiga komponen itu maka pegawai Dinas Pendapatan, Pengelolaan Keuangan dan Aset Kota Bengkulu telah memaksimalkan usahanya dalam menyelesaikan tugas.

Dukungan organisasional dari Dinas Pendapatan, Pengelolaan Keuangan dan Aset Kota Bengkulu dilihat baik dikarenakan adanya dukungan seperti memberikan pelatihan dan pengembangan kepada para pegawai, menyediakan peralatan dan teknologi yang baik, dan menetapkan standar kinerja yang sesuai.

\section{E. KESIMPULAN DAN SARAN}

1) Kesimpulan

Berdasarkan hasil penelitian dan pengujian hipotesis antara Hubungan Komunikasi dan Budaya Organisasi Dengan Kinerja Pegawai pada Dinas Pendapatan Pengelolaan Keuangan dan Aset (DPPKA) Kota Bengkulu dapat disimpulkan sebagai berikut:

1. Komunikasi di lingkungan Dinas Pendapatan Pengelolaan Keuangan dan Aset (DPPKA) Kota Bengkulu sudah baik dan mempunyai hubungan yang sangat erat dan signifikan dengan kinerja pada Dinas Pendapatan, Pengelolaan Keuangan dan Aset Kota Bengkulu.

2. Budaya Organisasi di lingkungan Dinas Pendapatan Pengelolaan Keuangan dan Aset (DPPKA) Kota Bengkulu sudah baik dan mempunyai hubungan yang erat dan signifikan dengan kinerja pegawai pada Dinas Pendapatan, Pengelolaan Keuangan dan Aset Kota Bengkulu. 


\section{2) Saran}

Adapun saran yang dapat menulis sampaikan adalah sebagai berikut Pimpinan hendaknya selalu menjalin komunikasi yang baik dan lancar kepada pegawainya serta selalu cepat menyampaikan pesan-pesan atau informasi penting yang berkaitan dengan tugas-tugas kepada bawahan, dengan bahasa yang mudah dipahami agar dapat meminimalisir kesalahan informasi dan pegawai tidak mengerjakan tugas dengan sia-sia.

Pimpinan juga mampu menciptakan dan meningkatkan budaya organisasi yang baik seperti peningkatan inisiatif individu pegawai dalam bekerja, saling membantu dan toleransi dengan pegawai maupun bagian lain yang sedang ada masalah kesulitan dalam menyelesaikan pekerjaan serta meningkatkan budaya organisasi yang positif lainnya supaya komitmen pegawai dapat mencapai kinerja yang lebih maksimal.

Saran lanjutan dari penelitian ini adalah agar peneliti lainnya dapat mengkaji yang lebih luas cakupannya mengenai apa saja yang dapat mempengaruhi kinerja pegawai dan dapat meningkatkan kinerja tersebut baik dari aspek yang dikaji maupun jumlah responden atau cakupan wilayah penelitian, karena masih banyak variabel lain yang berhubungan dengan kinerja pegawai yang belum terungkap dalam penelitian ini

\section{DAFTAR PUSTAKA}

Arikunto, Suharsimi. (2014). Prosedur Penelitian Suatu Pendekatan Praktik. Jakarta: RinekaCipta

Bangun, Wilson. (2012). Manajemen Sumber Daya Manusia. Jakarta : Erlangga.

Effendy, Onong Uchjana. (2014). Dinamika Komunikasi. Bandung: Remaja Rosdakarya

Mas'ud, Fuad. (2012). Manajemen Sumber Daya Manusia. Semarang: Undip

Mathis, Robert L. dan Jhon H. Jackson. (2014). Manajemen Sumber Daya Manusia. Alih Bahasa oleh Jimmy Sadeli. Jakarta: Salemba Empat

Purwanto, Djoko. (2011). Komunikasi Bisnis. Jakarta : Erlangga

Robbins, Stephen P. (2009). Perilaku Organisasi. Jakarta : Prenhallindo

Singarimbun, Masri dan Sofyan Effendy. (2014). Metode Penelitian Survey. Jakarta LP3ES

Sopiah, (2008). Perilaku Organisasional. Yogyakarta :Andi

Sugiyono. (2014). Metode Penelitian Bisnis. Bandung: Alfabeta

Umar, Husein. (2013). Riset Sumber Daya Manusia dalam Organisasi, Jakarta: Gramedia Pustaka Utama

Veithzal, Rivai. (2010). Manajemen Sumber Daya Manusia Untuk Perusahaan. Jakarta: Rajawali Pers

http://staffnew.uny.ac.id. Komunikasi dan kinerja pegawai 